\title{
The angiogenic gene profile of circulating endothelial progenitor cells from ischemic stroke patients
}

\author{
Vascular Cell 5:3 ～DOI: 10.1186/2045-824X-5-3 I c c Li et al.; licensee Publiverse Online S.R.L. 2013 \\ Received: 2 Oct 2012 | Accepted: 29 Oct 2013 | Published: 6 Oct 2013 \\ Navarro-Sobrino Míriam, Hernández-Guillamon Mar, Fernandez-Cadenas Israel, Ribó Marc, \\ Romero Ignacio A, Couraud Pierre-Olivier, Weksler Babette Barbash, Montaner Joan, Rosell Anna ${ }^{@}$ \\ + Contributed equally ${ }^{@}$ Corresponding author
}

\section{Abstract}

\section{Background}

The identification of circulating endothelial progenitor cells (EPCs) has introduced new possibilities for cellbased treatments for stroke. We tested the angiogenic gene expression of outgrowth endothelial cells (OECs), an EPC subtype capable to shape vessel structures.

\section{Methods}

OECs (at colony or mature stages) from ischemic stroke patients $(n=8)$ were characterized using the RT ${ }^{2}$ Profiler ${ }^{\mathrm{TM}}$ human angiogenesis PCR Array, and human microvascular endothelial cells (hCMEC/D3) were used as an expression reference of endothelial cells.

\section{Results}

Colony-OECs showed higher expression of $C C L 2, I D 3, I G F-1, M M P 9, T G F B R 1, T N F A I P 2, T N F$ and TGFB1 . However, BAI-1 , NRP2 , THBS1 , MMP2 and VEGFC expression was increased in mature-OECs $(\mathrm{p}<0.05)$. ID3 $(\mathrm{p}=0.008)$ and TGFBR1 $(\mathrm{p}=0.03)$ genes remained significantly overexpressed in colony-OECs compared to mature-OECs or hCMEC/D3. MMP9 levels were significantly increased in colony-OECs $(\mathrm{p}=0.025)$ compared to mature-OECs. Moreover, MMP-2, VEGF-C, THBS1 and NRP-2 gene expression was also significantly increased in mature-OECs compared to hCMEC/D3 $(\mathrm{p}<0.05)$. Some of these genes were positively validated by RT-PCR.

\section{Conclusion}

Our study shows that OECs from stroke patients present higher levels of pro-angiogenic factors at early stages, decreasing in mature OECs when they become more similar to mature microvascular endothelial cells.

\section{Keywords}

Ischemic stroke - Angiogenesis - Endothelial progenitor cells - Gene expression - Vasculogenesis

\section{Introduction}

Endothelial progenitor cells (EPCs) is a minor population of circulating mononuclear cells that participates in adult neovascularization in pathological and physiological processes. Current research on EPCs in adults 
holds great promise and is receiving much attention due to their contribution to neoangiogenesis in vascular injuries, such as wound healing, limb ischemia, myocardial infarction, atherosclerosis or stroke [1].

An approach to isolate EPCs from peripheral blood utilizes in vitro culture and produces two distinct EPC subtypes which have been named circulating angiogenic cells or "early EPCs" (eEPCs) and "outgrowth endothelial cells" (OECs). OECs are also known as endothelial colony-forming cells (ECFCs) or late EPCs because of their late appearance in culture and their ability to grow from expanding colonies [2]. OECs have been directly involved in vascular repair by forming perfused human neo-vessels when injected

subcutaneously into immune deficient mice [ 3]. It has already been demonstrated that OECs are more efficiently isolated from ischemic stroke patients than control subjects together with their ability to shape capillary-like structures in vitro [4]. For the specific purpose of vascular disease modelling, OECs should be the preferred EPC subtype to use, and a better understanding of their angiogenic characteristics in their different stages could be very useful to assess their regenerative potential in cell based therapies for ischemic stroke patients. However, the molecular features that de fine OECs differentiation in ischemic stroke patients are still unknown.

To better understand the molecular program of OECs in ischemic stroke, our aim was to examine the angiogenesis-related gene expression profile of OECs from ischemic stroke patients at initial colony (colonyOECs) or mature stages (mature-OECs), and compared them to mature human cerebral microvascular endothelial cells (hCMEC/D3) as a reference of endothelial cell expression.

\section{Materials and methods}

\section{Ethics statement}

The study was approved by the Ethics Committee of our institution and conducted in accordance with the Declaration of Helsinki. All patients or relatives and healthy controls gave written informed consent.

\section{Isolation and culture EPCs}

Peripheral blood $(20 \mathrm{ml})$ was obtained in EDTA-anticoagulated tubes from patients who had suffered a nonlacunar ischemic stroke ( $\mathrm{n}=8$ ) involving the middle cerebral artery (MCA) territory between $24 \mathrm{~h}$ and 7 days after onset of symptoms, and who had been admitted to the emergency department of our center. OECs were isolated from peripheral blood as previously described [ 4]. Colony-OECs appeared as rounded expanding colonies, while later acquisition of confluent cobblestone-shaped in monolayers was identified as matureOECs (Figure $1 \mathrm{~A}$ ). hCMEC/D3 cells, which are derived by immortalization of human brain primary microvascular endothelial cells were grown as previously described [ 5]. Additionally, EPCs from sex- and age-matched control subjects free of ischemic events, inflammatory or infectious diseases $(n=17)$ were initially cultured but cell cultures did not yield OEC cells.

\section{Figure 1}




\section{A Colony-OECs}

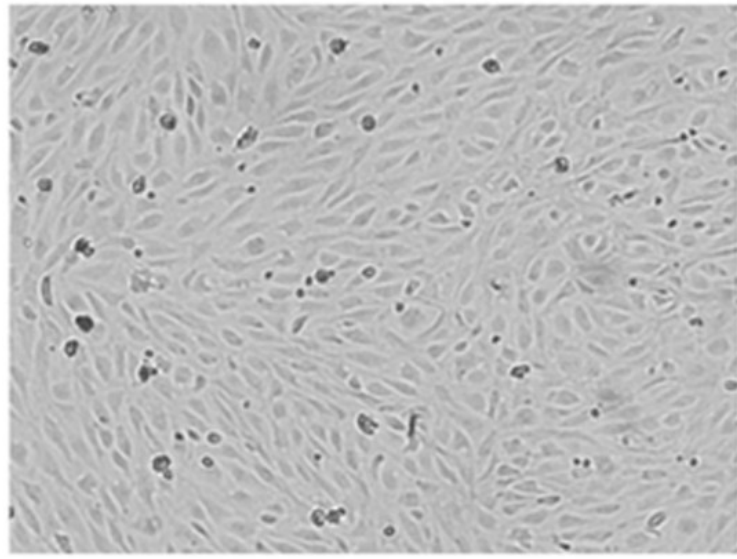

\section{Mature-OECs}

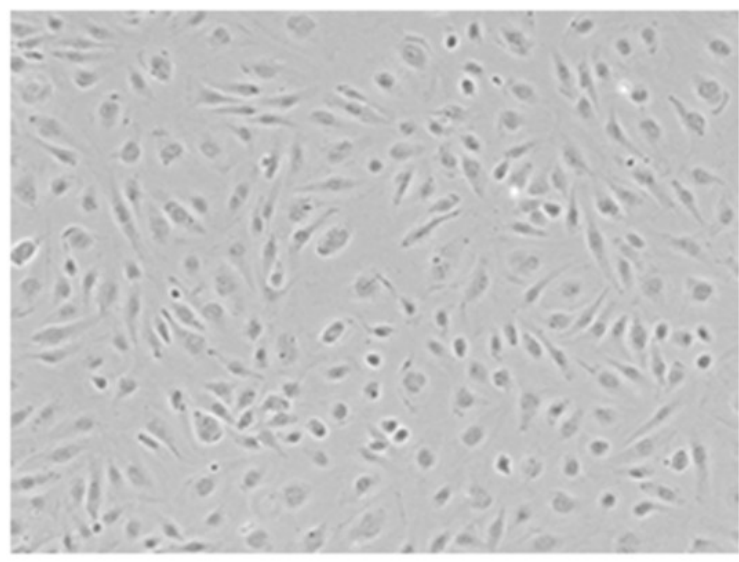

hCMEC/D3

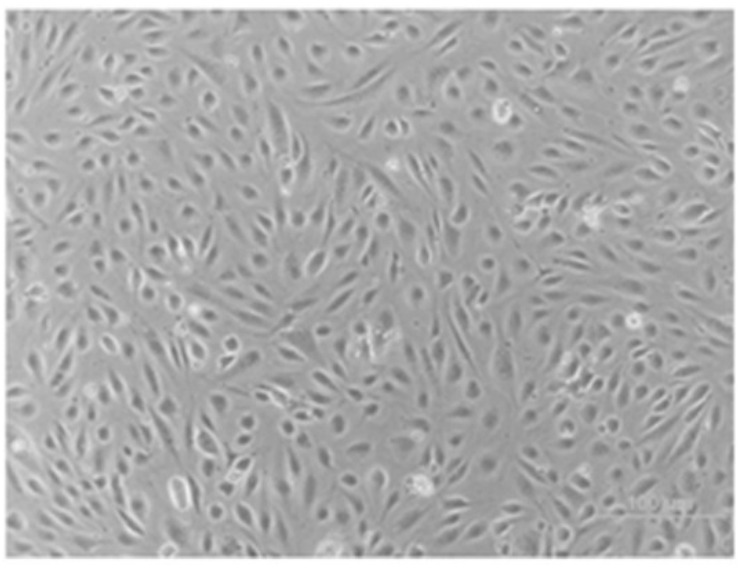

B

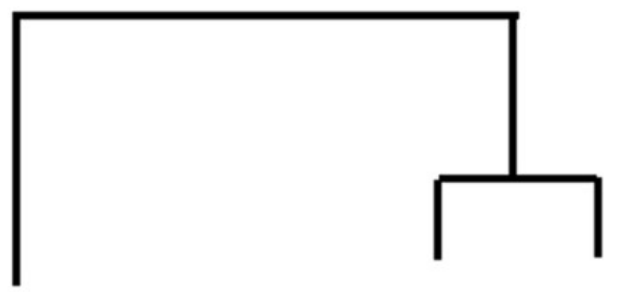

\section{Colony-OECs Mature-OECs hCMEC}
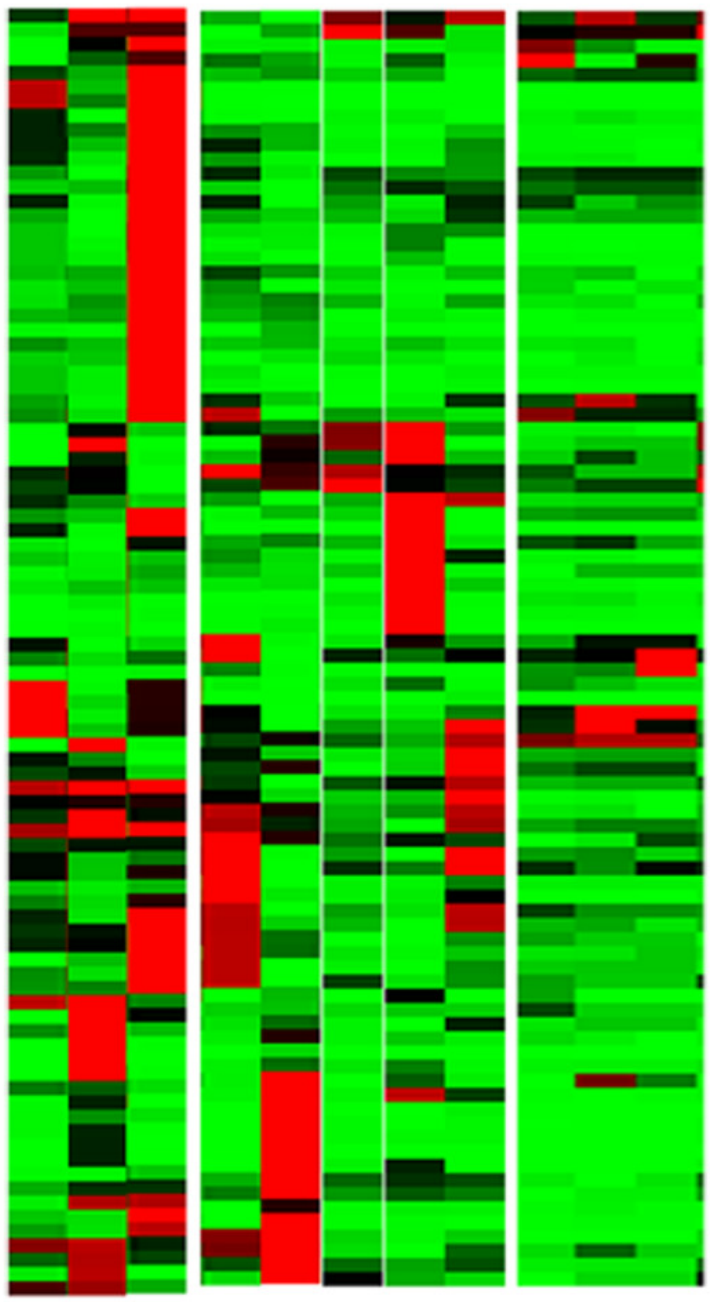

Magnitude gene expression

$\max$

Representative cell culture images and gene expression profile of the studied cells. A) Representative phase contrast images of colony-OECs (40x magnification) and mature-OECs (100x magnification) from ischemic stroke patients and hCMEC/D3 (100× magnification). B) Heat maps illustrating geneexpression profile of patients included in colony-OECs, mature-OECs and hCMEC/D3 groups. The green color indicates low expression and the red color indicates high expression.

A detailed history of any concomitant medication was obtained from each patient and all were scored for stroke severity and neurological status on admission and on follow-up visits according to the National Institutes of Health Stroke Scale (NIHSS). Functional outcome was defined by modified Rankin Scale (mRS) at three months and patients with $\mathrm{mRS}>2$ points were considered functionally dependent.

\section{RNA isolation and quality control}

RNA was obtained from cell cultures for both early-colony stage OECs and mature OECs. Since those cells obtained from the colony stage were not further expanded, different patients were included in the matureOECs group. The RNA from the mature-OECs was isolated from cells between the $4^{\text {th }}$ and $10^{\text {th }}$ passage 
since after 12 population doublings mature-OECs started to change their morphology probably undergoing to senescence. The colony-OECs were isolated before the first passage was done. Finally, hCMEC/D3 cells line was included as a reference of human endothelial cell type.

Colony-OECs obtained from ischemic stroke patients $(n=3)$ were isolated using a cell scraper. Mature-OECs $\left(1 \times 10^{5}\right.$ cells $\left./ \mathrm{mL}\right)$ taken between passages 4 and 10 from ischemic stroke patients $(n=5)$ and hCMEC/D3 $\left(1 \times 10^{5}\right.$ cells $\left./ \mathrm{mL}\right)$ at different passages (from 32 to $\left.34 ; \mathrm{n}=3\right)$ were seeded in twelve-well plates with EGM-2 (Clonetics ${ }^{\circledR}, \mathrm{CA}, \mathrm{USA}$ ) and maintained until confluence reached about $90 \%$. A total of 11 samples were included in the study. Total RNA was extracted with the RNeasy Mini kit (Qiagen, CA, USA). The RNA concentration and quality were measured using the Bioanalyzer 2100 system (Agilent, CA, USA). All samples presented high-quality RNA with RNA integrity numbers above 8.5. cDNA was pre-amplified using $\mathrm{RT}^{2}$ Nano PreAmp cDNA Synthesis Primer Mix Human Angiogenesis kits according to manufacturer's instructions (SabBioscience, Qiagen). RT $^{2}$ Profiler human angiogenesis PCR array was performed for quantitative PCR in the ABI 7000 system (Applied Biosystems, USA) with the following cycling conditions; 10 min at $95^{\circ} \mathrm{C}, 15 \mathrm{~s}$ at $95^{\circ} \mathrm{C}, 1 \mathrm{~min} 60^{\circ} \mathrm{C}$ for 40 cycles with a final infinite $4^{\circ} \mathrm{C}$ hold.

\section{Data normalization}

Five endogenous control genes glucuronidase $\beta$ ( GUS $\beta$ ), hypoxanthine guanine ( HPRT1), heat-shock protein 90 ( HSP90), glyceraldehyde phosphate dehidrogenase ( GAPDH), and $\beta$ actin ( ACT $\beta$ )] present on the $\mathrm{RT}^{2}$ Profiler human angiogenesis PCR Array were used for data normalization. Each replicate cycle threshold $(\mathrm{Ct})$ was normalized to the geometric median $\mathrm{Ct}$ of 5 endogenous controls per plate. $\mathrm{Ct}$ was defined as 35 for the $\Delta \mathrm{Ct}$ calculation when the signal was under detectable limits. The relative amount of transcripts in the colony-OECs and mature-OECs samples was calculated compared to our expression reference in hCMEC/D3. Results were calculated using the $2^{-\Delta \Delta C t}$ method [ 6]. Changes in gene expression between colony-OECs, mature-OECs and hCMEC/D3 cells are shown as a fold increase or decrease. Heat maps (color-coded graphs with groups in columns and genes in rows) were generated by using the web based program of $\mathrm{RT}^{2}$ profiler PCR Array Data Analysis.

\section{Real time PCR analysis}

Quantitative Real-time PCR (qRT-PCR) was used to measure mRNA expression levels of $M M P 2, M M P$, $V E G F-C, N R P-2$ and THBSI as a validation of the array data. Those probes were available in our laboratory, therefore the selection of genes for validation was random and not dependant on the significance level or the fold change. The same samples $(\mathrm{n}=11)$ used in the $\mathrm{RT}^{2}$ Profiler human angiogenesis PCR Array were included. The mRNA levels were quantified using TaqMan Hs00234422_m1 MMP2 (for MMP2), Hs00234579_m1 MMP9 (for MMP9), VEGFC Hs00153458_m1 VEGFC (for VEGF-C), Hs00962908_m1 THBS1 (for THBS1), Hs00187290_m1 NRP2 (for NRP-2) and Hs00181777_m1 BAI1 (for BAI1). The expression of the housekeeping gene peptidylprolylisomerase A ( PPIA ; probe Hs99999904_m1) was quantified as a reference to normalize all values. Real-time PCRs were run in triplicate and analyzed using the Applied Biosystems SDS 7500 system software (Applied Biosystems). The results are expressed as percentages based on a calibration sample used in all experiments.

\section{Statistical analysis}

The statistical significance was set at p value less than 0.05 and a mean difference equal to or greater than 2fold change in expression levels. Normal distribution of the variables was tested using the Shapiro-Wilk test. Differences between colony-OECs, mature-OECs and hCMEC/D3 groups were determined using the OneWay ANOVA or Kruskal Wallis and Mann Whitney tests for normal and non-normal distributions, respectively. Data were expressed as mean fold change \pm SD for normal distributed variables or median (interquartile range) for non-normal distributed variables. All statistical analyses were performed with SPSS version 15.0 software. To account for multiple statistical testing, false discovery rate (FDR) $q$-values were calculated.

\section{Results}

The stroke patients included in the study were under different secondary prevention treatments. One patient in each study-group was receiving oral anticoagulation therapy, 2 patients in colony-OECs and 3 in matureOECs group were under antiplatelet agents. In addition, 2 patients in colony-OECs group and 3 in matureOECs group were under statins. Moreover, a patient in the colony-OECs group showed a previous stroke.Baseline NIHSS was similar in patients from colony-OECs and mature-OECs groups ( $14 \pm 7.2$ vs. 8.2 $\pm 5.8 ; \mathrm{p}=0.297$ respectively) and also NIHSS at discharge ( $12.3 \pm 6.5$ vs. $11.6 \pm 15.9 ; \mathrm{p}=0.513$ respectively). Regarding functional outcome no differences were found between patients from colony-OECs and mature- 
OECs groups ( $4 \pm 2$ vs. $2.4 \pm 2.2 ; \mathrm{p}=0.263$ respectively). None of the analyzed genes showed any correlation between their expression level and the clinical outcome. White blood cell counts of the stroke patients included in the study were not statistically different $(\mathrm{p}=0.65)$.

The Human Angiogenesis RT ${ }^{2}$ Profiler PCR Array profiles the expression of 84 key genes involved in the biological processes of angiogenesis. Over $90 \%$ of the transcripts $(n=75)$ were detected whereas the expression of ANGPT1 ,CXCL9 ,IL8,COL18A1 ,COLAA3 ,CCL11, HAND2 ,IFN-G and TIMP-3 was undetected by this technique. Quality control parameters included in the Human Angiogenesis RT2 Profiler PCR Array (positive PCR controls and reverse transcription controls) showed a good reproducibility and efficiency based on the web based program of RT2 profiler PCR Array Data Analysis.

Overall, the analysis of the heat maps showed that mature-OECs gene-expression pattern partially matched hCMEC/D3 (Figure 1 B). Our results showed that in the colony-OECs group, 45 genes were overexpressed whereas only 13 genes were underexpressed. Similarly, the mature-OECs group showed 31 genes overexpressed and 15 underexpressed compared to hCMEC/D3 cells. At the same time, we only identified 13 genes displaying a significantly different expression between colony-OECs and mature-OECs and all of them were overexpressed in OECs compared to hCMEC/D3 as shown in Table 1.

\section{Table 1}

$<$ bold $>$ Identification of differentially expressed transcripts between the Colony- or Mature-OECs compared to hCMEC/D3 cells $</$ bold $>$

\begin{tabular}{|c|c|c|c|c|c|}
\hline Symbol & Gene name & $\begin{array}{l}\text { Colony-OECs fold } \\
\text { change }(n=3)\end{array}$ & $\begin{array}{l}\text { Mature-OECs fold } \\
\text { change }(n=5)\end{array}$ & $\begin{array}{c}\mathbf{p} \\
\text { value }\end{array}$ & $\begin{array}{c}q \\
\text { value }\end{array}$ \\
\hline ID3 & Inhibitor of DNA binding 3 & $4.5 \pm 0.4 * \#$ & $2.1 \pm 1.4$ & 0.008 & 0.750 \\
\hline TNFAIP2 & $\begin{array}{l}\text { Tumor necrosis factor alpha- } \\
\text { induced protein } 2\end{array}$ & $47.2(13-455)$ \# & $3.9(1-9)$ & 0.018 & 0.750 \\
\hline TGF $\beta R 1$ & $\begin{array}{l}\text { Transforming growth factor } \\
\text { beta receptor } 1\end{array}$ & $3.5(3-28) \#$ & $1.8(0.7-2)$ & 0.030 & 0.750 \\
\hline TGF $\beta 1$ & $\begin{array}{l}\text { Transforming growth factor } \\
\text { beta } 1\end{array}$ & $2.2 \pm 0.2 *$ & $1.4 \pm 0.7$ & 0.036 & 0.750 \\
\hline CCL2 & $\begin{array}{l}\text { Chemokine (C-C motif) ligand } \\
2\end{array}$ & $48.7(28-117) * \#$ & $12.8(0.7-20)$ & 0.036 & 0.500 \\
\hline THBS1 & Thrombospondin 1 & $22.7(19-23)$ & $5.8(3-30) *$ & 0.037 & 0.375 \\
\hline BAI 1 & $\begin{array}{l}\text { Brain-specific angiogenesis } \\
\text { inhibitor } 1\end{array}$ & $43(12-103)$ & $14.2(2-33) *$ & 0.037 & 0.600 \\
\hline MMP2 & Matrix metallopeptidase 2 & $508.7(306-600) *$ & $67.2(32-595) *$ & 0.042 & 0.333 \\
\hline NRP2 & Neuropilin 2 & $76.9(22-185)$ & $12.7(9-238) *$ & 0.043 & 0.300 \\
\hline TNF & Tumor necrosis factor & $320.4(39-531) *$ & $0.9(0.5-9)$ & 0.046 & 0.313 \\
\hline IGF1 & Insulin-like growth factor 1 & $\begin{array}{c}11393.9(1682-13738) \\
* \#\end{array}$ & $1.4(0.8-8)$ & 0.046 & 0.341 \\
\hline VEGFC & $\begin{array}{l}\text { Vascular endothelial growth } \\
\text { factor C }\end{array}$ & $5.7(2-6)$ & $5(3-9) *$ & 0.048 & 0.268 \\
\hline MMP9 & Matrix metalloprotease 9 & $2125.8(627-2563)^{* \#}$ & $0.6(0.1-2)$ & 0.049 & 0.250 \\
\hline
\end{tabular}

Data are expressed as mean fold change $\pm \mathrm{SD}$ or median (interquartile range) as appropriate.

$* \mathrm{p}<0.05$ and fold change $\geq 2$ Colony-OECs or Mature-OECs vs hCMEC/D3 cells; \# $\mathrm{p}<0.05$ and fold change $\geq 2$ Colony-OECs vs Mature-OECs.

CCL2 showed an increase in colony-OECs compare to mature-OECs or hCMEC/D3 cells [fold change 48.7 (28-117); $\mathrm{p}=0.036$ ] . ID3 was also increased in colony-OECs when compared to others groups [fold change $4.5 \pm 0.4 ; \mathrm{p}=0.008]$. Moreover, $I G F-1$ and $M M P 9$ were also overexpressed in colony-OECs compared to both mature-OECs and hCMEC/D3 [fold change 11393.9 (1682-13738) and 2125.8 (627-2563), respectively] as shown in Table 1. TNF and TGF $\beta 1$ showed higher gene expression [fold change 320.4 (39531 ) and $2.2 \pm 0.2$, respectively] in colony-OECs compared to hCMEC/D3. Interestingly, TGF $\beta R 1$ and TNFAIP2 also showed an increase [fold change 3.5 (3-28) and 47.2 (13-455), respectively] only in colonyOECs compared to mature-OECs.

On the other hand, we observed a significant increase in $B A I-1$ in mature-OECs compared to hCMEC/D3 [fold change 14.2 (2-33); $\mathrm{p}=0.037$ ]. Similarly, our results showed that NRP2, THBS1 and VEGFC were increased in mature-OECs when compared to hCMEC/D3 [fold change 12.7 (9-238); 5.8 (3-9) and 5 (3-9), 
respectively] as shown in Table 1. Finally, only the expression of $M M P 2$ was overexpressed in both colonyOECs and mature-OECs compared to hCMEC/D3 [fold change 508.7 (306-600) and 67.2 (32-595), respectively]. After performing Bonferroni post-test analysis for multiple comparisons in normal-distributed genes, only ID3 and TGF $\beta R 1$ genes remained significantly overexpressed in colony-OECs compared to mature-OECs or hCMEC/D3. Finally, when applying a correction for multiple testing on all distributed genes an alyzed, none of the $q$ values obtained was statistically significant (Table 1).

To validate our results by another technique MMP2, MMP9, VEGF-C, THBS1 and NRP-2 mRNA expression was measured using qRT-PCR. Figure $2 \mathrm{~A}$ shows that $M M P 9$ levels were significantly increased in colony-OECs $(\mathrm{p}=0.025)$ compared to mature-OECs and also overexpressed compared to hCMEC/D3 $(\mathrm{p}=0.05)$. In colony-OECs we also observed a trend to increased $M M P 2$ levels compared to hCMEC/D3 $(\mathrm{p}=0.05)$ and a significant overexpression in mature-OECs compared to hCMEC/D3 ( $\mathrm{p}=0.025)$; see Figure 2 B. Moreover, VEGF-C, THBS1 and NRP-2 gene expression was also significantly increased $(\mathrm{p}=0.034)$ in mature-OECs compared to hCMEC/D3 as shown in Figure 2. Figure 2

Validation of $M M P 2, M M P 9, V E G F-C, T H B S 1$ and NRP2 mRNA levels by qRT-PCR. A) MMP9 mRNA levels in colony-OECs $(\mathrm{n}=3)$ and mature-OECs $(\mathrm{n}=5)$. B) $M M P 2$ mRNA levels in colony-OECs $(\mathrm{n}=3)$ and mature-OECs $(n=5)$. C) VEGF-C gene expression levels in mature-OECs $(n=4)$ and hCMEC/D3 $(n=3)$. D) THBS1 mRNA levels in mature-OECs $(n=4)$ and hCMEC/D3 $(n=3)$. E) NRP-2 mRNA in mature-OECs $(n=4)$ and hCMEC/D3 $(n=3)$. Expression level is relative to calibrator sample and dashed line indicates median expression for hCMEC/D3 reference. $* \mathrm{p}<0.05$ (colony vs. mature-OECs); \# $\mathrm{p}<0.05$ (vs. hCMEC/D3).

This data confirms the results obtained in the RT2 profiler PCR Array and validates the analysis.

\section{Discussion}

This study reveals for the first time the angiogenic gene-expression profile of OECs from ischemic stroke patients. Our results show that early colony-OECs from ischemic stroke patients display higher expression of proangiogenic-related genes, while expression of these set of genes in more mature populations (matureOECs) is more similar to human cerebral microvascular endothelial cells.

A recent study has revealed changes in gene expression of late outgrowth EPC-derived endothelial cells from systemic sclerosis patients that could contribute to the endothelial dysfunction and may be relevant to the development of the vasculopathy [7]. However, it is completely unknown the gene expression profile of EPCs from ischemic stroke patients.

Other authors have studied the differentiation process of cord blood-derived EPCs showing that the first stage involves the expression of genes related to cell adhesion to extracellular matrix; during the second stage, gene-expression profile reveals transcription of cell cycle and antiapoptotic genes; finally, after the proliferative stage, adherent EPCs acquire additional endothelial-specific characteristics through the expression of endothelial markers [ 8]. Our results in the present study show that some of the genes previously described as expressed in EPCs from cord blood or peripheral blood of healthy volunteers such as $I G F-1, M M P 9, M M P 2$ and ID3 [ 8,9] are also expressed in EPCs from ischemic stroke patients. Additionally, it is known that $I G F-1$ is highly expressed in EPCs compared to mature endothelial cells or monocytes enhancing EPC differentiation involving PI3-kinase/phosphorylated Akt pathways of cell survival and proliferation [ 10,11]. Our data also confirms that $I G F-1$ mRNA level is also increased in colony-OECs derived from stroke patients, suggesting a role for $I G F-1$ during the differentiation process of these cells.

Furthermore, it is well established that secreted matrix metalloproteinases (MMPs) from EPCs have a pivotal role in the ischemia-induced neovascularization since they actively participate in matrix degradation [ 12]. In this context, we show that $M M P 9$ and $M M P 2$ are highly expressed in colony-OECs, further reinforcing the functional properties of this population. We also successfully validated the $M M P 2, M M P 9, V E G F-C$, THBS1 and NRP-2 results by qRT-PCR showing that the RT2 profiler PCR Array is a good method to assess gene expression levels even when differences in expression are small.

In addition, our findings also prove the overexpression of ID3 and TGF $\beta R 1$ genes in colony-OECs, suggesting a role in the proliferation and differentiation of colony-OECs to endothelial cells. In fact, previous reports have demonstrated that ID3 - /- mutant mice show a markedly impaired EPC mobilization [ 9] and TGF $\beta R 1$ has also been involved in the mobilization and differentiation of cord blood-derived EPCs [ 13]. Recently, the capacity of EPCs to support the activity and function of resident differentiated cells by paracrine mechanisms has focused increased attention [14]. Our study also demonstrates that colony-OECs 
show a higher proangiogenic gene expression pattern, suggesting that colony-OECs could potentially present a higher secretion of angiogenic growth factors.

The current study has revealed that the gene expression profile of mature-OECs from ischemic stroke patients partially resembles that of hCMEC/D3 cells. Recently, it has been reported that OECs acquire additional endothelial-specific characteristics based on transcriptomic-, proteomic-, and ultrastructuralanalysis [ 15]. Consistent with that study, our results also demonstrate that mature-OECs show an increase in $M M P 2, T H B S 1$ and $V E G F-C$, reinforcing the endothelial nature of mature-OECs. Interestingly, we also observe an increase in mature-OECs expression of BAI-1 , a member of the secretin receptor family involved in the inhibition of angiogenesis, supporting the hypothesis that angiogenesis is controlled by a local balance between stimulators and inhibitors.

In the context of cerebral ischemia, the first pre-clinical studies testing the therapeutic potential of EPCs administrated early EPCs [ 16, 17] but lately, new studies are exploring the role of OECs [ 18]. It is important to define the nature of these cells in culture to identify the best population for transplantation.

A recent publication demonstrated that time in culture conditions did not alter phenotype of OECs with no significant change in antigen expression between early (passage 0-2), mid (passage 4-6) and late passage (passage 6-9) cells. Furthermore, they confirmed that late outgrowth endotelial progenitor cells resembled mature human umbilical vein endothelial cells (HUVEC) [ 19].

In conclusion, the present study shows that the expression pattern of the angiogenic-related genes from OECs of ischemic patents changes during their expansion but preserves the pro-angiogenic potential despite the ischemic insult. Therefore, it would be of great value to determine in which differentiation stage (i.e., whether colony or mature) would OECs be more effective in cell-based therapies, making them an attractive tool to be tested for autologous transplantation after ischemic stroke.

This study certainly includes some limitations. We included stroke patients between $24 \mathrm{~h}$ and 7 days after onset of symptoms because we demonstrated in a previous study that OECs from subacute strokes (obtained after $24 \mathrm{~h}$ of the symptoms onset) showed a higher expression and secretion of angiogenic factors than OECs obtained in the first hours following stroke [ 4]. However, the temporal profile of OECs maturation in terms of angiogenic factors gene expression needs to be confirmed at different time points in a larger cohort of stroke patients. We focused our study in ischemic stroke patients because cell cultures from sex- and agematched controls did not yield OECs under the same cell culture conditions. In this regard, we have already demonstrated that circulating EPCs are reduced in control subjects compared to stroke patients [4]. Moreover, other authors have shown that hormonal status influences circulating EPC levels being significantly reduced in postmenopausal women related to reduce estradiol levels [ 20]. Since our control group was primarily composed by women in menopausal age $(76.5 \%, 70.6 \pm 7.4$ years old) this could also partially explain our difficulty. Finally, it would be interesting to compare gene expression patterns of OECs with those of primary endothelial cells. However, the advantage of using hCMEC/D3 cells is that they model the human blood brain barrier (BBB) and avoid the inherent variability as well as the difficulty of sourcing that apply to primary endothelial cultures. Further studies, must confirmed our results in a larger number of patients and further explored at functional level to define its biological implications.

\section{Declarations}

\section{Acknowledgements}

AR is supported by the Miguel Servet programme (CP09/00265) from the Spanish Ministry of Health (Instituto de Salud Carlos III). This work has been funded by Instituto de Salud Carlos III, grant PI10/00694 and the Spanish stroke research network RENEVAS (RD06/0026/0010) co-financed by the European Regional Development Fund (ERDF). This work has been supported also by the European Union's Seventh Framework Programme (FP7/2007-2013) under grant agreements n ${ }^{\circ} 201024$ and n 202213 (European Stroke Network).

\section{Authors' original submitted files for images}

Below are the links to the authors' original submitted files for images.

Authors' original file for figure 1

Authors' original file for figure 2 


\section{Competing interest}

The authors declare that they have no competing interests.

\section{Authors' contributions}

M N-S carried out the array experiments, statistical analysis and wrote the paper. AR guided the research, analyzed the results and critiqued each draft of the manuscript. M H-G participated in the design of the study and helped to draft and review the manuscript. MR participated in the collection of the blood samples. I F-C performed the RT-PCR study. J M designed and helped to draft the manuscript. IR, P-OC and BBW are contributing authors since they provided the hCMEC/D3 cells under a Material Transfer Agreement. All authors read and approved the final version of the manuscript.

\section{References}

1. Rafii S, Lyden D. Therapeutic stem and progenitor cell transplantation for organ vascularization and regeneration. Nat Med. 2003;9:702-712.

View Article Google Scholar

2. Yoder MC Mead LE Prater D Krier TR Mroueh KN Li F Krasich R Temm CJ Prchal JT Ingram DA Redefining endothelial progenitor cells via clonal analysis and hematopoietic stem/progenitor cell principals Blood 20071091801 18091801067 10.1182/blood-2006-08043471

3. Reinisch A Hofmann NA Obenauf AC Kashofer K Rohde E Schallmoser K Flicker K Lanzer G Linkesch W Speicher MR Strunk D Humanized large-scale expanded endothelial colonyforming cells function in vitro and in vivo Blood 2009113671667252710924 10.1182/blood-2008-09-181362

4. Navarro-Sobrino M, Rosell A, Hernandez-Guillamon M, Penalba A, Ribó M, Alvarez-Sabín J, Montaner J. Mobilization, endothelial differentiation and functional capacity of endothelial progenitor cells after ischemic stroke. Microvasc Res. 2010;80:317-323.

View Article Google Scholar

5. Weksler BB, Subileau EA, Perrière N, Charneau P, Holloway K, Leveque M, Tricoire-Leignel H, Nicotra A, Bourdoulous S, Turowski P, Male DK, Roux F, Greenwood J, Romero IA, Couraud PO. Blood-brain barrier-specific properties of a human adult brain endothelial cell line. FASEB J. 2005; 19:1872-1874.

View Article Google Scholar

6. Livak KJ, Schmittgen TD. Analysis of relative gene expression data using real-time quantitative PCR and the 2(-Delta Delta C(T)). Method. 2001;25:402-408.

View Article Google Scholar

7. Avouac J, Cagnard N, Distler JH, Schoindre Y, Ruiz B, Couraud PO, Uzan G, Boileau C, Chiocchia G, Allanore Y. Insights into the pathogenesis of systemic sclerosis based on gene expression profile of progenitor-derived endotelial cells. Arthritis Rheum. 2011;63:3552-3562.

View Article Google Scholar

8. Igreja C, Fragoso R, Caiado F, Clode N, Henriques A, Camargo L, Reis EM, Dias S. Detailed molecular characterization of cord blood-derived endotelial progenitors. Exp Hematol. 2008;36:193-203.

View Article Google Scholar

9. Lyden D, Hattori K, Dias S, Costa C, Blaikie P, Butros L, Chadburn A, Heissig B, Marks W, Witte L, Wu Y, Hicklin D, Zhu Z, Hackett NR, Crystal RG, Moore MA, Hajjar KA, Manova K, Benezra R, Rafii S. Impaired recruitment of bone-marrow-derived endothelial and hematopoietic precursor cells blocks tumor angiogenesis and growth. Nat Med. 2001;7:1194-1201. 
10. Thum T, Hoeber S, Froese S, Klink I, Stichtenoth DO, Galuppo P, Jakob M, Tsikas D, Anker SD, Poole-Wilson PA, Borlak J, Ertl G, Bauersachs J. Age-dependent impairment of endothelial progenitor cells is corrected by growth-hormone-mediated increase of insulin-like growthfactor-1. Circ Res. 2007;100:434-443.

View Article Google Scholar

11. Urbich C, Aicher A, Heeschen C, Dernbach E, Hofmann WK, Zeiher AM, Dimmeler S. Soluble factors released by endothelial progenitor cells promote migration of endothelial cells and cardiac resident progenitor cells. J Mol Cell Cardiol. 2005;39:733-742.

View Article Google Scholar

12. Huang PH, Chen YH, Wang CH, Chen JS, Tsai HY, Lin FY, Lo WY, Wu TC, Sata M, Chen JW, Lin SJ. Matrix metalloproteinase-9 is essential for ischemia-induced neovascularization by modulating bone marrow-derived endothelial progenitor cells. Arterioscler Thromb Vasc Biol. 2009;29:1179-1184.

View Article Google Scholar

13. Moonen JR, O'Neill CL, Sweeney M, Guduric-Fuchs J, Gardiner TA, Simpson DA, Stitt AW. Endothelial progenitor cells give rise to pro-angiogenic smooth muscle-like progeny. Cardiovasc Res. 2010;86:506-515.

View Article Google Scholar

14. Wyler von Ballmoos M Yang Z Völzmann J Baumgartner I Kalka CD Endothelial progenitor cells induce a phenotype shift in differentiated endothelial cells towards PDGF/PDGFR $\beta$ axis-mediated angiogenesis PLoS One 20105 e141072991332 10.1371/journal.pone.0014107

15. Medina RJ O'Neill CL Sweeney M Guduric-Fuchs J Gardiner TA Simpson DA Stitt AW Molecular analysis of endothelial progenitor cell (EPC) subtypes reveals two distinct cell populations with different identities BMC Med Genomics 20103 182881111 10.1186/17558794-3-18

16. Ohta T, Kikuta K, Imamura H, Takagi Y, Nishimura M, Arakawa Y, Hashimoto N, Nozaki K. Administration of ex vivo-expanded bone marrow-derived endothelial progenitor cells attenuates focal cerebral ischemia-reperfusion injury in rats. Neurosurgery. 2006;59:679-686. View Article Google Scholar

17. Fan Y Shen F Frenzel T Zhu W Ye J Liu J Chen Y Su H Young WL Yang GY Endothelial progenitor cell transplantation improves long-term stroke outcome in mice Ann Neurol 2010 674884973026588 10.1002/ana.21919

18. Moubarik C, Guillet B, Youssef B, Codaccioni JL, Piercecchi MD, Sabatier F, Lionel P, Dou L, Foucault-Bertaud A, Velly L, Dignat-George F, Pisano P. Transplanted late outgrowth endothelial progenitor cells as cell therapy product for stroke. Stem Cell Rev. 2011;7:208-220.

View Article Google Scholar

19. Tura O, Skinner EM, Robin Barclay G, Samuel K, Gallagher RC, Brittan M, Hadoke PW, Newby DE, Turner ML, Mills NL. Late outgrowth endothelial cells resemble mature endothelial cells and are not derived from bone marrow. Stem Cells. 2012;:-.

View Article Google Scholar

20. Bulut D, Albrecht N, Imöhl M, Günesdogan B, Bulut-Streich N, Börgel J, Hanefeld C, Krieg M, Mügge A. Hormonal status modulates circulating endotelial progenitor cells. Clin Res Cardiol. 2007;96:258-263.

View Article Google Scholar 